\title{
Olistostromes in the Miocene salt-bearing folded deposits at the front of the Ukrainian Carpathian orogen
}

\author{
Oleh HNYLKO ${ }^{1, *}$ \\ 1 Institute of Geology and Geochemistry of Combustible Minerals of NAS of Ukraine, Naukova 3a, 79060 Lviv, Ukraine
}

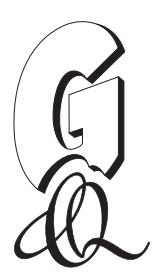

Hnylko, O., 2014. Olistostromes in the Miocene salt-bearing folded deposits at the front of the Ukrainian Carpathian orogen. Geological Quarterly, 58 (3): 381-392, doi: 10.7306/gq.1132

\begin{abstract}
The origin of the olistostromes at the front of the Ukrainian Carpathian orogen is related to Miocene synsedimentary thrust movements of the Carpathian accretionary prism and to erosion of uplifted areas of the Boryslav-Pokuttya Nappe in the front of the accretionary prism. There are two olistostrome complexes. The first is the Lower Miocene Polyanytsia-Vorotyshcha Olistostrome with clasts of molasse and flysch deposits formed in a piggy-back basin on the inner part of the Boryslav-Pokuttya Nappe at the top of the accretionary wedge. This olistostrome is associated with the Sloboda Conglomerate derived from the fore-bulge at the foreland of the Boryslav-Pokuttya Nappe. The second one is the Middle Miocene Lanchyn Olistostrome with olistoliths of strongly deformed molasse deposits. These olistoliths were slid from the uplifted front of the Boryslav-Pokuttya Nappe. The Lanchyn Olistostrome was deposited at front of this nappe in a foredeep basin.
\end{abstract}

Key words: Miocene, olistostrome, debris-flow, nappe, synsedimentary tectonics, Ukrainian Carpathians.

INTRODUCTION

Olistostromes often take part in the structure of orogens. Flores (1959) proposed using the term "olistostrome" to the formation containing two binding components. The first component is a matrix composed of typically sandy-clayey deposits with chaotic or poorly layered sedimentary textures. The second component is an olistolith represented by large blocks of rock embedded in a matrix. It was considered that the olistostrome is a sufficiently large mappable unit. Commonly, the olistostrome is very thick and extends for tens, in places hundreds of kilometres (Leonov, 1981). The terms "matrix" and "olistolith" are depend on the scale under consideration; for example small blocks are referred to as olistoliths in exposures, and the same blocks can be depicted as part of the matrix on geological maps. The matrix is the product of debris-flows accompanying submarine landslides. Olistoliths are represented by relatively coherent transported blocks of rocks.

Olistostromes reflect mass-wasting processes and gravity-induced emplacement of unsorted sediments and may be associated with turbidites and mudflow deposits. Any rock type available in the uplifted source area may contribute to the formation of an olistostrome including salt-bearing rocks (Ślączka and Kolasa, 1997).

Recently the origin of the olistoliths and olistostromes from the Polish Carpathians was discussed by Cieszkowski et al.

\section{*E-mail: ohnilko@yahoo.com}

Received: May 5, 2013; accepted: September 23, 2013; first published online: November 20, 2013
(2009). In the Ukrainian Carpathian orogen, most of the thick (hundreds of metres) and best-expressed olistostromes are grouped into several zones which are characterized by a subCarpathian strike and are confined to the frontal parts of the great nappes (Hnylko, 2011; Fig. 1). They have been described in the Marmarosh Klippen Zone (Kruglov, 1965), and at the front of the Marmarosh (Byzova, 1965), Chornohora (Gruzman and Smirnov, 1985), Dukla (Glushchenko, 1972; Glushchenko et al., 1980; Hnylko, 2000) and Silesian (Astakhov, 1989) nappes. Olistostromes are also known from the Polyanytsia Formation and the Vorotyshcha salt-bearing Formation within the Boryslav-Pokuttya Nappe (Unit) (Kulchitskiy, 1977).

As a result of field research a new olistostrome was identified and partially mapped at the front of the Boryslav-Pokuttya Nappe among the salt-bearing deposits of the Sambir Nappe (Unit) (Hnylko and Vashchenko, 2003, 2004).

In the Ukrainian Outer Carpathians, nappe-related olistostromes are represented by synorogenic chaotic deposits with mainly flysch olistoliths derived from the uplifted orogenic flysch-nappe front advancing towards the foreland region (Hnylko, 2011).

Olistostromes containing exotic clasts derived from the preflysch and/or platform basement uplifted and exposed to mass-wasting at the basin margin are also known from the Ukrainian Outer Carpathians. These olistostromes often form relatively thin sedimentary lenses of debris-flow deposits with exotic clasts, or are part of mixed complexes containing olistoliths derived both from the uplifted flysch nappes and from the elevated basement (Hnylko, 2011). For example, a thick sequence of the Sloboda Conglomerate is associated with the nappe-related olistostrome embedded in the Polyanytsia and Vorotyshcha formations. A conglomerate regarded as of alluvial fan origin (with a high contribution of high-density gravity flow deposits) is followed by a fan 


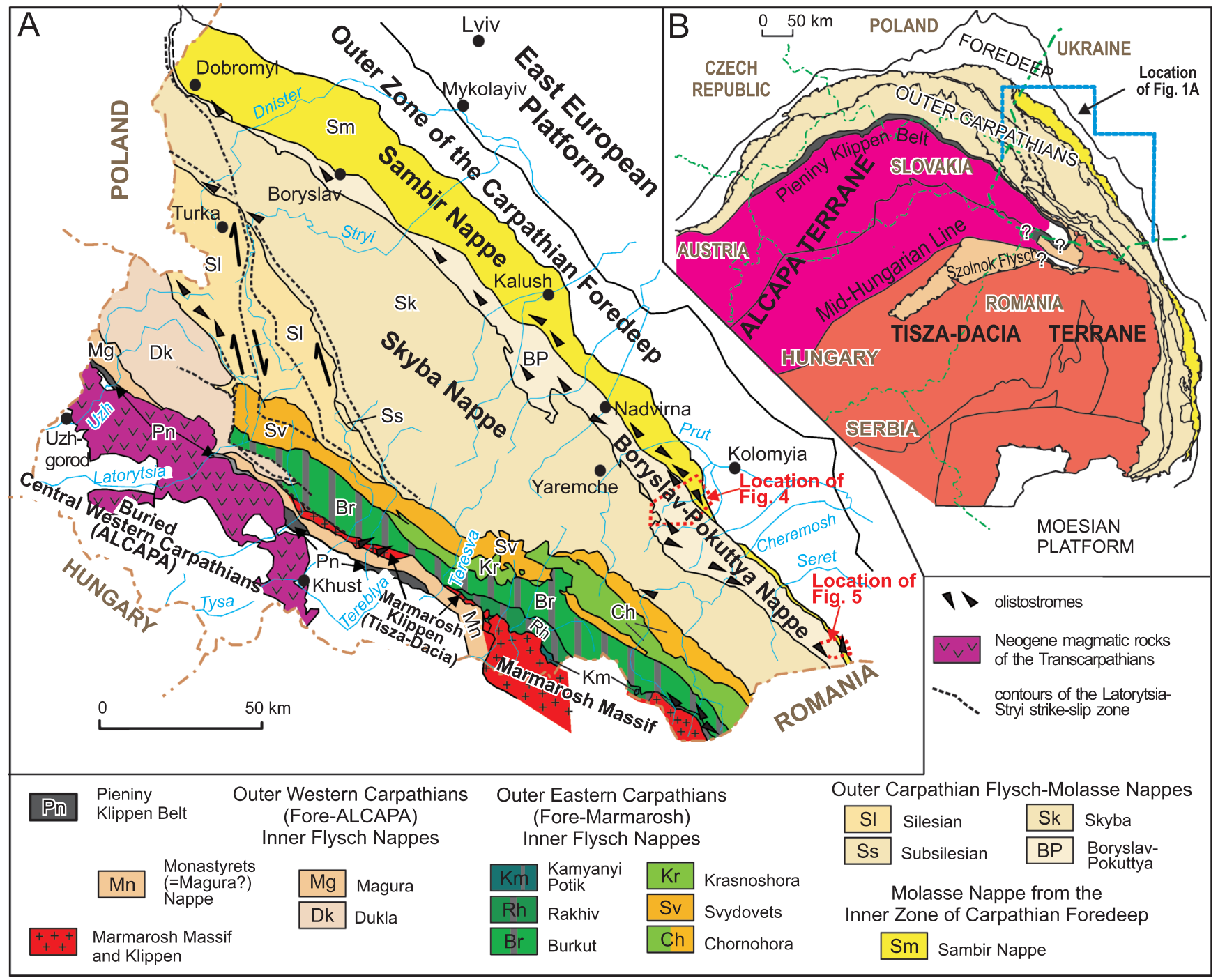

Fig. 1A - main tectonic units of the Ukrainian Carpathians (Hnylko, 2012); B - tectonic setting of the Ukrainian Carpathians, position of the terranes and main geological boundaries after Kovač et al. (1998); Csontos and Vörös (2004); Schmid et al. (2008); simplified, partly modified

delta succession (Oszczypko et al., 2012). Clasts of the Sloboda Conglomerate were derived from the platform forebulge that was formed as a consequence of thrust movements of the Carpathian orogen (Hnylko and Vashchenko, 2003, 2004; Hnylko, 2011; Oszczypko et al., 2012).

In the present paper the geological position, structure and origin of the olistostromes from the Miocene salt-bearing deposits of the Boryslav-Pokuttya and Sambir nappes are described. Olistostromes were investigated in exposures along the banks of major rivers during preparation of the geological map of the Boryslav-Pokuttya and Sambir nappes, at the scale of 1:200,000 (in Vashchenko et al., 2009).

\section{GEOLOGICAL SETTING}

The Boryslav-Pokuttya and Sambir nappes extend along the front of the Ukrainian Outer Carpathians. The Outer Carpathians involve several stacked nappes (also referred to as "units") and are considered as the Cretaceous-Neogene accretionary prism formed as a result of subduction of the basement of the Carpathian sedimentary flysch basin beneath the ALCAPA and Tisza-Dacia terranes, which now are located in the inner part of the Carpathian mountain arc (Kovač et al., 1998; Csontos and Vörös, 2004; Oszczypko, 2006; Hnylko, 2012; Fig. 1). The Outer Carpathian nappes are thrust over the Neogene molasse-fill of the Carpathian Foredeep.

The Ukrainian Carpathian Foredeep is filled with synorogenic Miocene molasse. This molasse is folded and detached from its sedimentary substrate in the Inner Zone of the Carpathian Foredeep. The Outer Zone of the Carpathian Foredeep (named the Bilche-Volytsia Zone) is not folded and rests directly on the platform basement. The main part of the Inner Zone dips southward under the Outer Carpathian nappes.

In Ukraine the Miocene salt-bearing folded molasse deposits with olistostromes are developed along the front of the Outer Carpathians. These deposits belong to the Boryslav-Pokuttya and Sambir nappes (Figs. 1 and 2). The Boryslav-Pokuttya Unit forms the frontal nappe of the Outer Carpathians (Glushko et al., 1982; Hnylko, 2012). The Sambir Nappe is derived from the Inner Zone of the Neogene Carpathian Foredeep. Some authors (Kruglov, 1986) regard the Boryslav-Pokuttya Nappe as a 


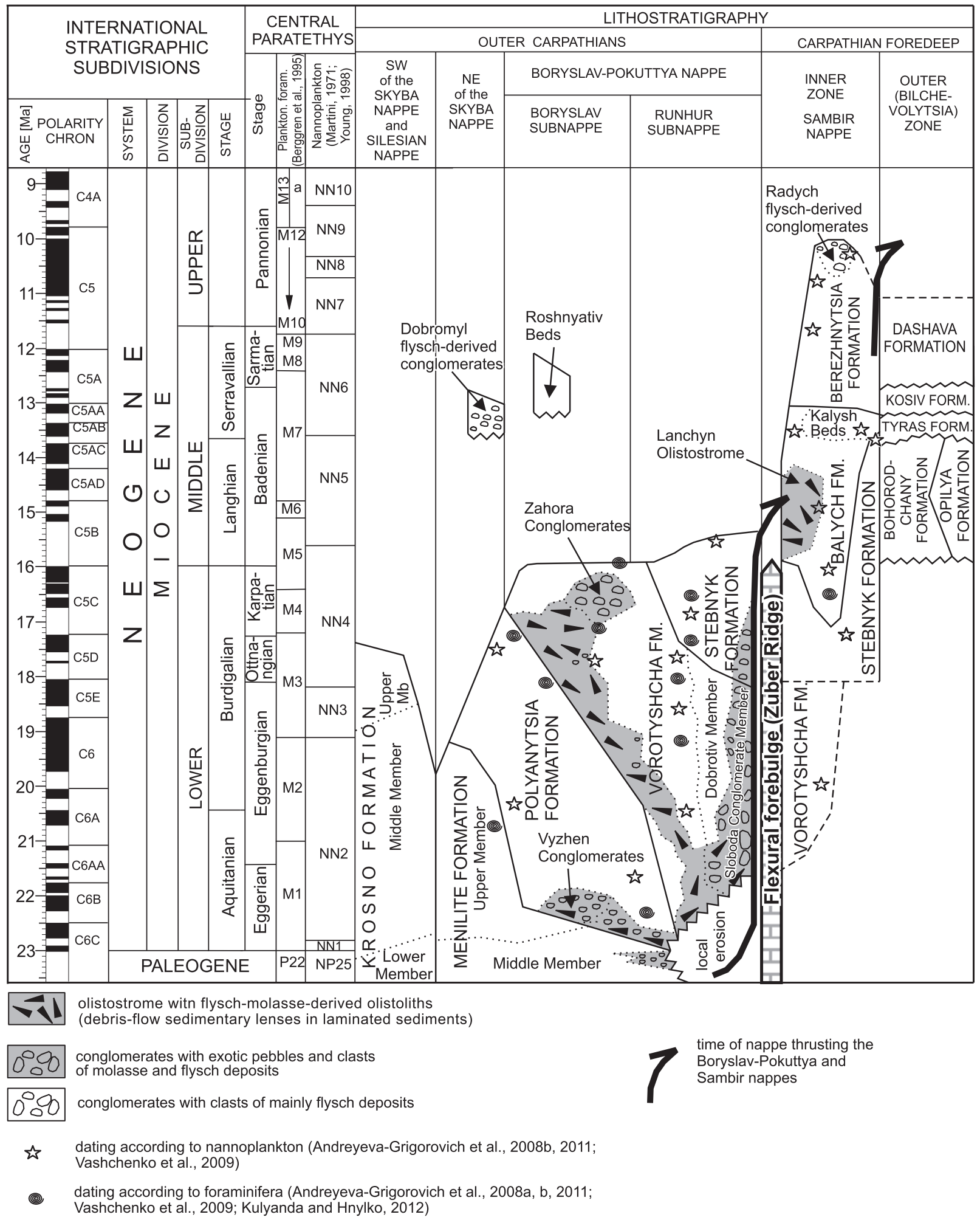

Fig. 2. Regional stratigraphic scheme of the Neogene deposits of the Outer Carpathians and Carpathian Foredeep (Andreyeva-Grigorovich et al., 2011, simplified and partly modified) and olistostromes and conglomerates

tectonic unit derived from the Inner Zone of the Carpathian Foredeep.

Miocene deposits are represented by the upper part of the Menilite Formation and a number of molasse formations, according to the new regional stratigraphic scheme of the Neogene deposits of the Outer Carpathians and Carpathian Fore- deep (Andreyeva-Grigorovich et al., 2011; Fig. 2). This scheme differs from other more "traditional" schemes (Andreyeva-Grigorovich et al., 1997; Smirnov, 2003; Oszczypko et al., 2006; Jankowski et al., 2012) by the steeply inclined up to sub-vertical (strongly diachronous) boundaries of the formations. It should be emphasized that the boundaries are oblique 
and not vertical (with the exception of the Skyba successions which are separated one from another and where the Miocene parts of the Menilite and Krosno formations are not directly in contact with each other). A new regional stratigraphic scheme of the Neogene was built both on the grounds of geological observations of relationships of the lithostratigraphic units during geological mapping of the region, and, on the basis of new biostratigraphic data. In 1999-2001 and 2006-2008 we selected samples from the Miocene deposits along the banks of major rivers crossing the Sambir and Boryslav-Pokuttya nappes in Ukraine for the analysis of microfauna and nannoplankton. Unfortunately very few of them yielded useful microfossils, and it was not always possible to precisely date the boundaries of formations biostratigraphically. Nevertheless some new dating by foraminifera and nannoplankton suggest diachronous borders (approximately coeval faunas were found in the Menilite and Polyanytsia formations; in the Polyanytsia and Vorotyshcha formations; in the Vorotyshcha and Stebnyk formations and in the Stebnyk and Balych formations). These biostratigraphic data are in the report (Vashchenko et al., 2009) and partially published (Vashchenko and Hnylko, 2003a, b; Hnylko and Vashchenko, 2003, 2004; Andreyeva-Grigorovich et al., 2008b, 2011; Kulyanda and Hnylko, 2012). The most important biostratigraphic results are shown in Figure 2.

The Boryslav-Pokuttya Nappe is partly covered by the Skyba Nappe (Outer Carpathians) and thrust over the Sambir Nappe (see Fig. 1; Kruglov, 1986). The Boryslav-Pokuttya Nappe is subdivided into the inner Boryslav Subnappe in the south-west and the outer Runhur Subnappe in the north-east that differ in lithostratigraphic composition of the Miocene deposits (Vialov, 1965; Hnylko and Vashchenko, 2003, 2004; Fig. 2). The Boryslav-Pokuttya Unit is composed of dislocated Cretaceous-Lower Miocene flysch (mainly turbidites) and Miocene molasse. Flysch-molasse deposits are detached from their sedimentary substrate. Molasse covers the flysch conformably, in places with local erosion.

Miocene deposits are represented by the upper part of the Menilite Formation and the Polyanytsia, Vorotyshcha (including the Vorotyshcha Fm. sensu stricto consisting of mainly saltbearing clays, the Sloboda Conglomerate Member and the Dobrotiv Member) and Stebnyk formations (Andreyeva-Grigorovich et al., 2011; Fig. 2).

The Menilite Formation is composed mainly of black shales with interbedded chert and sandstone lenses (Kosakowski, 2013 with references therein). The thickness of the Menilite Formation in the Boryslav-Pokuttya Unit generally decreases from $\sim 1000 \mathrm{~m}$ to a few hundreds and even few tens of metres in a north-east direction. In the same direction the Menilite Formation lacks its middle and upper members due to their facies replacement by the Polyanytsia Formation (Fig. 2).

The Polyanytsia Formation (thickness up to $1000 \mathrm{~m}$ ) is represented by alternating grey clays, silts, claystones, siltstones and sandstone. It contains lenses of conglomerate, sedimentary breccia and debris-flow deposit, which increase in thickness and quantity to the north-east. The Vorotyshcha Formation (thickness up to $1200 \mathrm{~m}$ ) in the inner part of the Boryslav-Pokuttya Nappe (Boryslav Subnappe) is represented by salt-bearing gypsiferous semi-lithified grey clays with intercalations of grey sandstone and layers of sedimentary breccia, conglomerate and debris-flow deposit. In the Boryslav Subnappe the Vorotyshcha Formation represents the youngest lithostratigraphic unit of the stratigraphic succession (Andreyeva-Grigorovich et al., 2011).

In the Runhur Subnappe, salt-bearing shales and clays of the Vorotyshcha Formation are gradually replaced by the Dobrotiv Member (bedded sandstones with intercalations of grey shale) and Sloboda Conglomerate Member, which are overlain by the Stebnyk Formation (variegated shales, marls and sandstones, thickness up to $1200 \mathrm{~m}$ ).

The Sambir Nappe is covered by the Boryslav-Pokuttya Nappe and thrust over the Outer (Bilche-Volytsia) Zone of the Carpathian Foredeep. It is composed of dislocated Miocene molasse (Vorotyshcha, Stebnyk, Balych and Berezhnytsia formations) completely uprooted from their sedimentary basement (Andreyeva-Grigorovich et al., 2011). Kruglov (1986) considered the Sambir Unit as a joint zone located between the platform and flysch basin. Some researchers believe that the Sambir Basin (as well as the Boryslav-Pokuttya Basin) was situated on the top of the Carpathian accretionary wedge (in a piggy-back basin; Oszczypko et al., 2012) but flysch deposits were not found in the Sambir Unit. The sedimentary basement of the Miocene Sambir molasse basin seems to be represented by the platform dropped in front of the Carpathian orogen (foredeep basin) (Hnylko and Vashchenko, 2004; AndreyevaGrigorovich et al., 2011; Hnylko, 2012).

The Vorotyshcha Formation (thickness up to $1000 \mathrm{~m}$ ) within the Sambir Unit is represented by grey clays, silts, sands and sandstones. The lower surface of the Vorotyshcha Formation is cut off by faults. This phenomenon can be observed, for example, in outcrops along the Prut River.

The Stebnyk Formation (thickness up to $1000 \mathrm{~m}$ ) is composed of predominantly variegated clays, marls, shales with interbedded siltstones and sandstones. Near the border with Poland the Stebnyk Formation contains thick lenses of the Nyzhankovychi Conglomerate (Burov et al., 1976).

The Balych Formation (thickness up to $750 \mathrm{~m}$ ) generally is represented by greenish-grey thin-laminated, mainly calcareous clays with interbedded siltstones and sandstones. Olistostrome is presented locally and forms a thick lens among the bedded deposits at the front of the Boryslav-Pokuttya Nappe (Hnylko and Vashchenko, 2003, 2004). The upper part of the Balych Formation in some areas (e.g., Holynya, Kalush, Velykyi Belin) contains the Upper Badenian evaporite "Kalush Beds". The evaporite deposits of the Kalush area are correlated with the Upper Badenian salt of the Wieliczka and Bochnia region (Andreyeva-Grigorovich et al., 2003; see also discussion in Wójtowicz et al., 2003; Peryt, 2006).

The Kalush Evaporite Beds are overlain by upper Middle-lower Upper Miocene sandy-clayey marine deposits (thickness up to $1200 \mathrm{~m}$ ), which recently has been named as the Berezhnytsia Formation (Andreyeva-Grigorovich et al., 2011) (see Fig. 2). Previously most researchers (Andreyeva-Grigorovich et al., 1997) attributed those supra-evaporite strata (Berezhnytsia Formation) to the Kosiv and Dashava formations.

\section{DESCRIPTION OF THE OLISTOSTROMES}

Olistostrome in the Boryslav-Pokuttya Nappe was briefly described by Kulchitskiy (1977), who noted that the borehole deep samples and observations at outcrop fix the thick horizons with inclusions (olistostromes) to the bottom of the Polyanytsia Formation. The olistostromes are represented by a clay mass packed with fragments of ancient metamorphic rock, Jurassic limestone, with the inclusion of Eocene-Oligocene flysch rocks. This researcher also noted olistoliths of the Menilite Formation among the Zahora (Truskavets) conglomerates of the Vorotyshcha Formation. On the map prepared by Jankowski et al., $(2007,2012)$ the Vorotyshcha Formation is compared with the Slon Beds (olistostromes developed in Romania), but this comparison needs further testing. 
According to our mapping, olistostromes in the Boryslav-Pokuttya Nappe are developed as a number of lenses (several metres, tens or up to hundreds of metres thick) of debris-flow deposits (Fig. 3) within the layered strata of the Polyanytsia and Vorotyshcha formations (Polyanytsia-Vorotyshcha Olistostro$\mathrm{me}$ ). In the olistostrome between the lenses of debris-flow deposits can be found the thin layers of the background laminated clayey strata. The olistostrome tends to occur in the lower part of these formations, but in places (for example in the core of the Akreshory Syncline, see Fig. 4) throughout the greater part of the Vorotyshcha Formation. The matrix of the olistostrome consists of semi-lithified, often gypsiferous, grey and bluish clays with small clasts of redeposited molasse and locally flysch (usually Menilite Fm.) rocks. The matrix is characterized by poorly layered and chaotic sedimentary textures (Fig. 3A, B).

Olistoliths in the olistostrome from the inner (south-west) part of the Boryslav-Pokuttya Nappe (Boryslav Subnappe) are composed of Miocene grey mudstones, siltstones and sandstones of the Polyanytsia and Vorotyshcha formations; the Oligocene-Miocene dark bituminous shales of the Menilite For- mation; and, less often, Eocene muddy flysch. The pre-Miocene flysch rocks within the olistoliths are strongly deformed: crumpled into small folds, locally transformed into tectonic breccia. The olistostrome in places contains small lenses of coarse sand and gravel with exotic debris (greenschist fragments) (Fig. $3 C$ ). The thickness of the lens increases to the north-east, where the coarse sand and gravel are transformed into the Sloboda Conglomerates.

The olistostrome in the outer (north-east) part of the Boryslav-Pokuttya Nape (Runhur Subnappe) is gradually replaced by a olistostrome-conglomerate successin (the Sloboda Conglomerate Member and their analogues - Truskavets, Rushor, Krasnoilsk conglomerates) (Fig. 3D-F). It is a succession up to 600-m-thick of conglomerates, breccias, sandstones with clay intercalations. Clasts are represented by green and red schists, quartz, limestones and other exotic rocks (Fedushchak, 1962; Oszczypko et al., 2012) as well as black shales of the Menilite Formation. The conglomerate is associated in places with the olistostrome, with the olistoliths composed of Oligocene-Miocene bituminous shales (Menilite Fm.) and
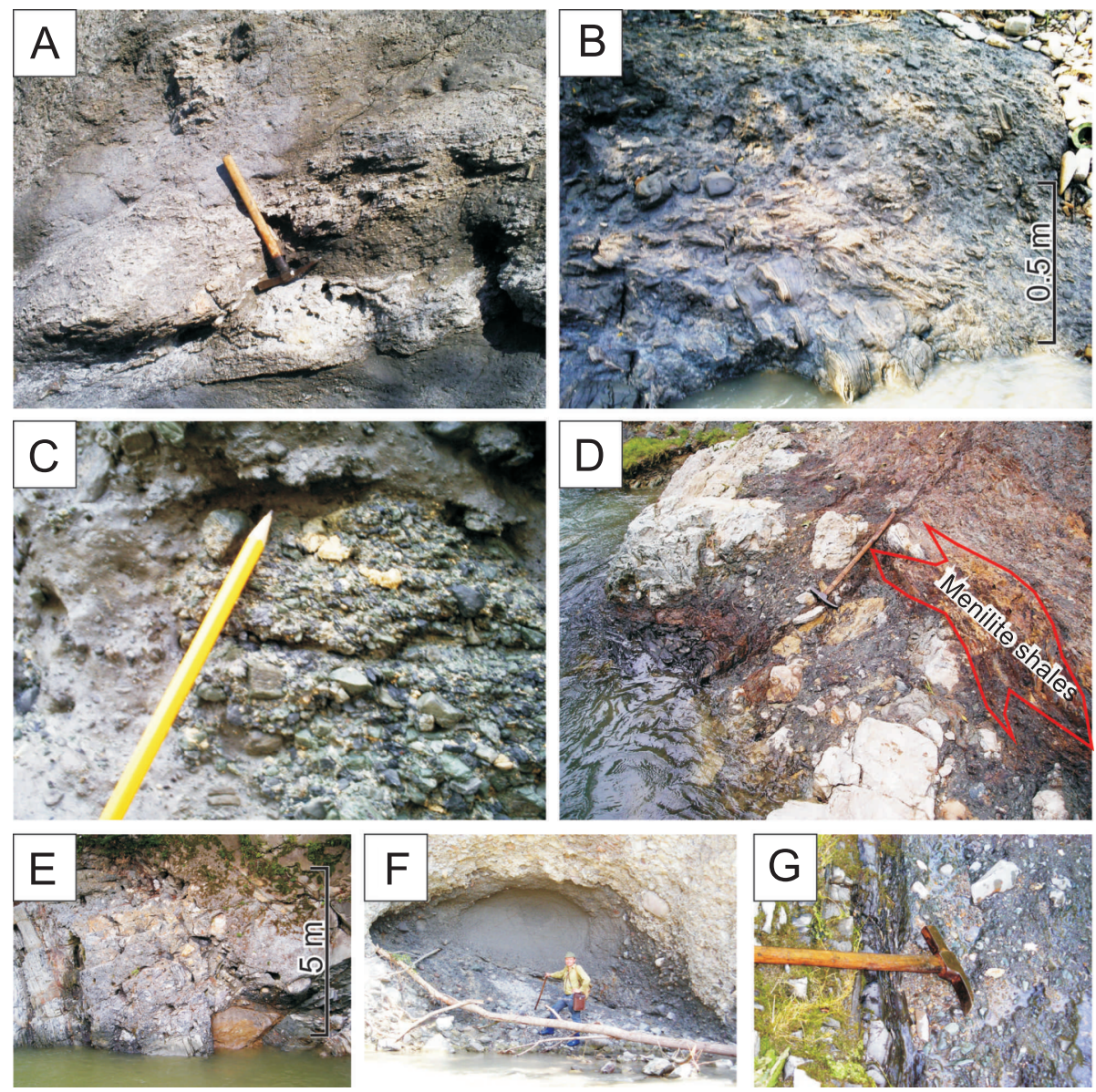

Fig. 3. Olistostromes and conglomerates of the Boryslav-Pokuttya Unit

A - matrix of the olistostrome of the Vorotyshcha Fm., sedimentary layering is poorly expressed (Luchka River basin); B - matrix of the olistostrome of the Vorotyshcha Fm. - debris-flow deposits with clasts of redeposited Vorotyshcha clays and sandstones (Luchka River basin); C - lens of gravel with exotic clasts within the Vorotyshcha clays (Luchka River basin); D - olistostrome with clasts of both exotic rocks and Menilite Shales (Polyanytsia Formation, Rybnytsia River near Kosiv); E - debris-flow lens in the Polyanytsia Formation (Rybnytsia River near Kosiv); F - unsorted Sloboda Conglomerate (Luchka River near Yabluniv); G - normal contact between Menilite Shales and Vyzhen ( $\approx$ Sloboda) Conglomerate (Vyzhenka River, Cheremosh River basin near Vyzhnytsa) 


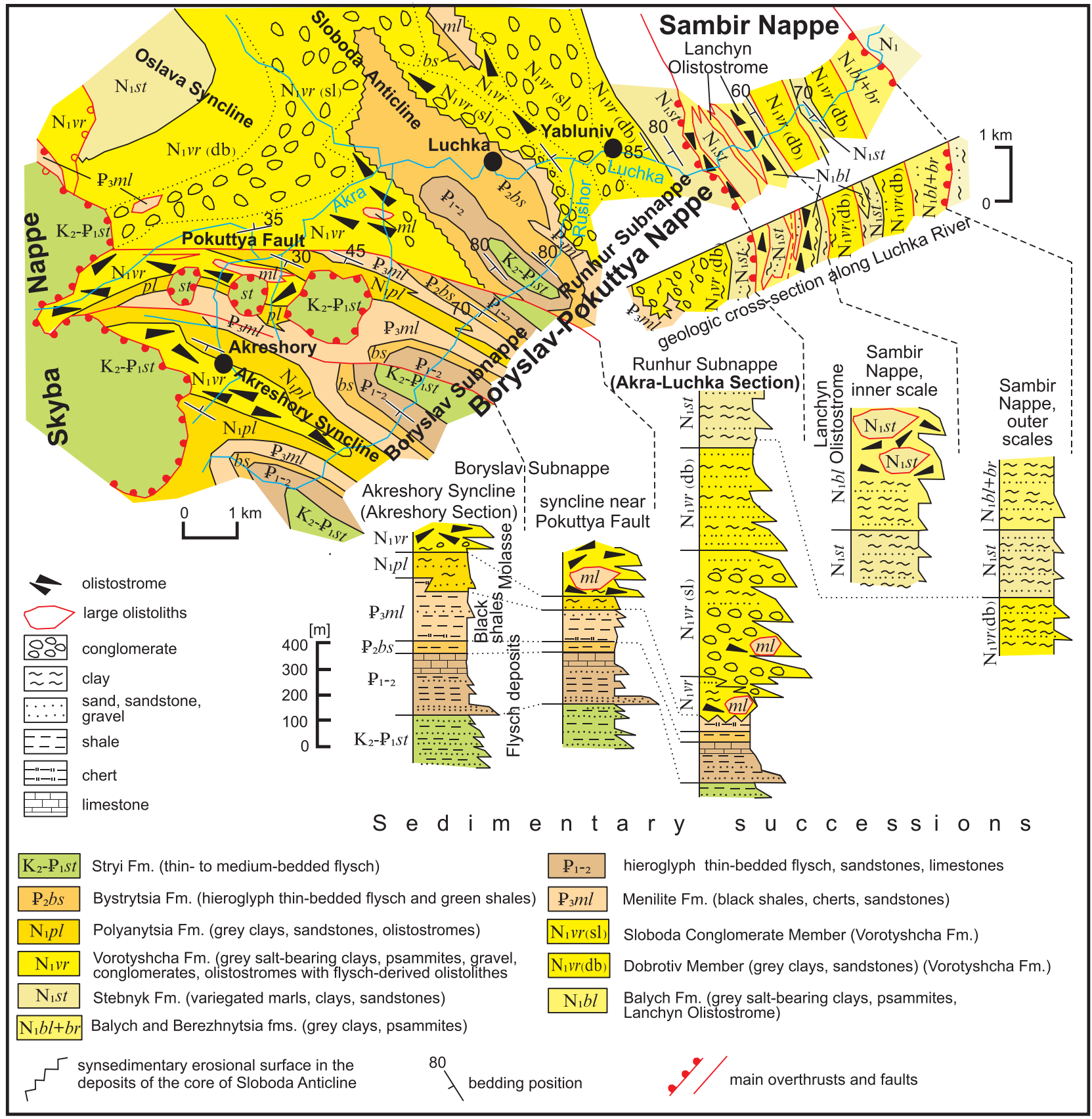

Fig. 4. Geologic map of the Boryslav-Pokuttya and Sambir units at the Luchka River basin and position of the olistostromes

For location see Figure 1

Eocene flysch (Fig. 3D). The conglomerate is often characterized by chaotic matrix-supported textures and is a debris-flow deposit (Fig. 3E, G).

Conglomerates at the bottom of the molasse in the Boryslav-Pokuttya Nappe lie conformably on the Menilite Formation (Fig. 3G), with local erosion but probably without a significant stratigraphic break. Furthermore, thin layers of gravel and fine conglomerates with exotic clasts occur within the Menilite Formation, indicating continuity of sedimentation from flysch to molasse.

The olistostrome and olistostrome-conglomerate successions (debris-flow deposits, some with large landslides-olistoliths) form sedimentary lenses at different levels of the Polyanytsia and Vorotyshcha formations and were probably deposited during accumulation of the Polyanytsia-Vorotyshcha strata
- from the earliest Miocene to the boundary of the Early-Middle Miocene (Andreeva-Grigorovich et al., 2011; Kulyanda and Hnylko, 2012).

Early Miocene, probably Eggerian, foraminifers were found in molasse strata containing a debris-flow lense (Fig. 3D) (Runhur Subnappe, Polyanytsia Formation along the Rybnytsia River near the Kosiv city). According to Trofymovych (in Vashchenko et al., 2009) these foraminifers comprise Globigerina ciperoensis ciperoensis Bolli, G. praebulloides aff. leroy Blow, G. praebulloides praebulloides Blow, Spiroloculina aff. lamposa Hussey, Cibicides amphisilensis (Andreae), Hanzawaia boueana (d'Orbigny), Ammodiscus cf. miocenicus Karrer, A. aff. tenuissimas Grzybowski and Reophax sp.

Early Miocene, probably Ottnangian-Karpatian foraminifers were found in molasse strata of the Polyanytsia Formation un- 
derlying the olistostrome of the Vorotyshcha Formation (Boryslav Subnappe, Pokuttya folds, Akra and Pistynka rivers). According to Chernukha (in Vashchenko et al., 2001) these foraminifers comprise Globigerinoides trilobus (Reuss), Globorotalia mayeri (Cushman et Ellis), Globoquadrina langiana Cita et Gelata, G. dehiscens (Chapman et al.) and Globigerina bolli Cita et Premoli Silva and others.

The youngest microfauna among the olistostroms of the Boryslav-Pokuttya Unit was established in the Vorotyshcha Formation at the northwestern part of the Ukrainian Carpathians near the border with Poland near the city of Dobromyl (the Ternavka Stream) as well near the city of Boryslav. At these locations the background clays embedded in the chaotic olistostrome deposits contain foraminifers (M. Kulyanda in Kulyanda and Hnylko, 2012) indicating an age close to the Early-Middle Miocene boundary: Globigerina bollii Cita et Premoli Silva; G. bulloides (d'Orbigny), Globigerinoides trilobus (Reuss), Globoquadrina dehiscens (Chapman et al.), Globigerinella obesa (Bolli), Globorotalia scitula (Brady), Paragloborotalia mayeri (Cushman et Ellis) (Andreyeva-Grigorovich et al., 2011; Kulyanda and Hnylko, 2012).

Well-developed sections of the Boryslav-Pokuttya and Sambir nappes outcrop along the banks of the Akra and Luchka rivers and their inflows (Fig. 4), where olistostromes are distributed among salt-bearing molasse. The structure of the Boryslav Subnappe, represented by the Pokuttya folds (Tołwiński, 1950), outcrops there in the upper Akra River. One of the Pokuttya folds the Akreshory Syncline - contains in its core an olistostrome (of thickness 100-150 m) attributed to the Vorotyshcha Formation (see Fig. 4).

The Akreshory Section (Boryslav Subnappe) is situated along the Akra River and contains the youngest deposits in the core of the Akreshory Syncline (see Fig. 4).

Below the village of Akreshory on the banks of the Akra River, there are outcropps of rocks belonging to the Polyanytsia Formation which are represented by the grey marly shales with intercalations of thin-bedded sandstone. There are several beds of massive sandstone (with thicknesses of 1-2 m) and lenses (up to 5-m-thick) of debris-flow deposits with clasts of the grey marly shale, of sandstone of the Polyanytsia Formation and of laminated siliceous limestone of the Menilite Formation. The thickness of the Polyanytsia Formation is about $150 \mathrm{~m}$. Downstream along the Akra River there is a gradual transition of the Polyanytsia Formation into the Menilite Formation composed of the dark grey bituminous mudstones. Upstream along the Akra River the Polyanytsia Formation gradually passes into Vorotyshcha Formation that is represented by an olistostrome composed of semi-lithified gypsiferous grey and bluish clays with clasts and blocks (up to metre in diameter) of the betterlithified sandstones and shales of the Polyanytsia Formation. There, olistoliths of the Menilite Formation and more ancient flysch formations were not found. At the bottom of the Vorotyshcha Olistostrome there are several layers (5-15-cm-thick) of laminated silts and clays. The olistostrome completes the stratigraphic succession of the Boryslav Subnappe and fills the core of the Akreshory synclinal fold. The olistoliths in this olistostrome may have been derived from the limbs of the Akreshory Syncline (which are composed of the Polyanytsia Formation, see Fig. 4) during synsedimentary folding.

Another syncline, comprising the olistostrome of the Vorotyshcha Fm. in the core, is located near the Pokuttya Fault dividing the Boryslav and Runhur subnappes in the area (see Fig. 4). The olistostrome (100-200-m-thick) contains rock fragments of the Polyanytsia Formation and in addition olistoliths of the Menilite Formation. The Polyanytsia and Menilite forma- tions form the syncline limbs which may be the source area for the Vorotyshcha Olistostrome.

The structure of the Runhur Subnappe of the BoryslavPokuttya Nappe is exposed along the Akra-Luchka River section (Fig. 4).

The Akra-Luchka Section (Runhur Subnappe) is situated along the Akra and Luchka rivers and contains the deposits filling the Sloboda Anticline (see Fig. 4).

In the southwestern limb of the Sloboda Anticline, near the confluence of the Akra and Luchka rivers green mudstones of the Bystrytsa Formation (Eocene) are exposed. $50 \mathrm{~m}$ higher along the Akra River there are the exposures of the Vorotyshcha Formation composed of grey layered semi-lithified clays and sandstones, and sedimentary breccias from the same clays and sandstones belonging to Vorotyshcha Formation. The contact between the Bystrytsia Formation and the Vorotyshcha Formation is not exposed, though the boundary between the two formations is probably erosive. Upstream along the Akra River there are exposures of greenish-grey laminated and massive, in places salt-bearing clays and sandstones of the Vorotyshcha Formation. The beds are gently dipping to sub-horizontal. The clays locally pass into breccia, rich in small fragments of siltstone and sandstone embedded in a pelitic matrix. Stratigraphically higher on the left bank of the Akra River is the Sloboda Conglomerate Member. The conglomerates are also exposed along the Akra River ( $400-750 \mathrm{~m}$ above its mouth) where it can be traced for 300-350 m along the banks of the Akra. They are composed of fragments of various sizes (up to a few decimetres or even metres across) of the schist, quartz, sandstone and black, in part variegated Eocene-Oligocene mudstone.

In the north-east limb of the Sloboda Anticline, 500 metres from the church in the village of Lucha, downstream along the Luchka River there are exposures of the Menilite Formation black mudstones, sandstones, flint-bearing levels and limestones. The Sloboda Conglomerate Member (Vorotyshcha Formation) can also be seen, lying on the eroded surface of the Menilite Formation. This matrix-supported conglomerate comprises debris-flow deposits with pebbles and blocks (up to several metre across) of green schist, quartz, sandstone and black mudstone of the Menilite Formation. Black mudstones reach olistolith, size up to $10 \mathrm{~m}$ across. A palaeochannel eroded by debris-flows occurs within the Menilite Formation, under the conglomerate.

Conglomerates extend downstream along the Luchka River a few tens of metres. Beneath, there are exposed stratified clays of the Vorotyshcha Formation which extend 500 m downwards along the Luchka River to the mouth of the Rushor Stream. Probably, these clays belong to the core of the local anticline (see Fig. 4). In left bank tributaries of the Luchka River, the stratified clays are replaced by olistostrome with a clayey matrix and olistoliths (up to tens of metres across) of black shales and sandstones of the Menilite Formation.

Near the mouth of the Rushor Stream, Dobrotiv-like grey clays interbedded with sandstones are observed. The Dobrotiv-like beds extending $150 \mathrm{~m}$ downwards along the Luchka River are overlain by the Sloboda Conglomerate Member. This member is composed of boulders and pebbles (Fig. 3E, F) of green, rarely variegated schists, quartzite-like Paleozoic(?) sandstone, quartz, limestone and dolomite, and other exotic clasts; they also contain a thick lens of debris-flow deposits with fragments (olistoliths) of the Menilite Formation and of Eocene flysch strata.

The Sloboda Conglomerate is traced down $250 \mathrm{~m}$ along the Luchka River and gradually passes into the Dobrotiv Member 
(Vorotyshcha Fm.) stratigraphically upwards. Under the bridge across the Luchka River (the road to the village of Kosmach) the Dobrotiv Member is exposed as thin rhythmic alternations of clays $(20-30 \mathrm{~cm})$ and siltstones $(5-10 \mathrm{~cm})$. These deposits can be traced downriver for $700 \mathrm{~m}$.

$750-800 \mathrm{~m}$ below the bridge on the Luchka, the first layers of pink clay appear, within grey clays. Stratigraphically above, variegated marls, sandstones and siltstones of the Stebnyk Formation are developed. They complete the stratigraphic succession of the Runhur Subnappe.

Beneath of the Runhur thrust, already within the Sambir Unit, outcrops of the gypsiferous unstructured grey clays can be observed, which contain olistoliths of the Stebnyk Formation (the Lanchyn Olistostrome, see below).

Our observations at other locations show that many olistolits in the Polyanytsia-Vorotyshcha Olistostrome of the Boryslav-Pokuttya Unit are generally similar to the deposits situated stratigraphically directly below of the olistostrome strata. This feature allows us to suggest that the Polyanytsia-Vorotyshcha Olistostrome was formed in the Boryslav-Pokuttya sedimentary basin "in situ" due to the erosion of its uplifted floor. Uplifted areas may have been formed during the growth of the anticlinal and/or thrust-anticlinal uplifts which supplied the material for olistoliths. Synsedimentary tectonics probably took place during the general elevation of the Boryslav-Pokuttya Unit due to its thrusting on the to platform.

The structural position and composition of the olistostrome in the Vorotyshcha and Polyanytsia formations suggests that it was formed due to erosion of the uplifted parts of the BoryslavPokuttya Nappe and deposited, instead of in the nappe front, in the inner part of the moving nappe. This supports the idea that olistostrome sedimentation took place on the top of the Carpathian accretionary flysch wedge (in a piggy-back basin).

The quantity and size of the clasts of the exotic non-flysch rocks of the Sloboda Conglomerate gradually increases from the inner to the outer part of the Boryslav-Pokuttya Unit. Such distribution of detrital material shows that the exotic clasts were supplied from the platform fore-bulge, which is compared with the previously known (Kruglov, 1986) Leżajsk Massif uplifted in the Early Miocene.

Therefore, both the exotic fragments derived from the platform forebulge and flysch clasts derived from nappe-related thrust-anticlinal elevations within the Boryslav-Pokuttya sedimentary basin were delivered by debris-flows into the piggy-back olistostrome-conglomerate Boryslav-Pokuttya molasse basin.

Olistostrome in the Sambir Nappe was discovered recently (Hnylko and Vashchenko, 2003). It extends as a strip hundreds of metres to a few kilometres in width ahead front of the Boryslav-Pokuttya Nappe only, and can be traced from the Seretel River basin (Fig. 5) near the Ukrainian-Romanian border up to the Kalush area (see Fig. 1).

This chaotic stratum, that outcrops along the Prut River near Lanchyn, was interpreted by Vialov (1965) as the "Lanchyn Blue Facies" of the Stebnyk Formation. We propose to call this stratum the "Lanchyn Olistostrome".

The interpretation of the structure of the Lanchyn Olistostrome is controversial. Some authors (Andreyeva-Grigorovich et al., 2008a) conclude that the matrix of the Lanchyn Olistostrome exposed along the Prut River is represented by the Stebnyk Formation and olistoliths are expressed by the grey chaotic gypsiferous clayey deposits derived from the Vorotyshcha Formation. Hnylko and Vashchhenko (2003) suggested that

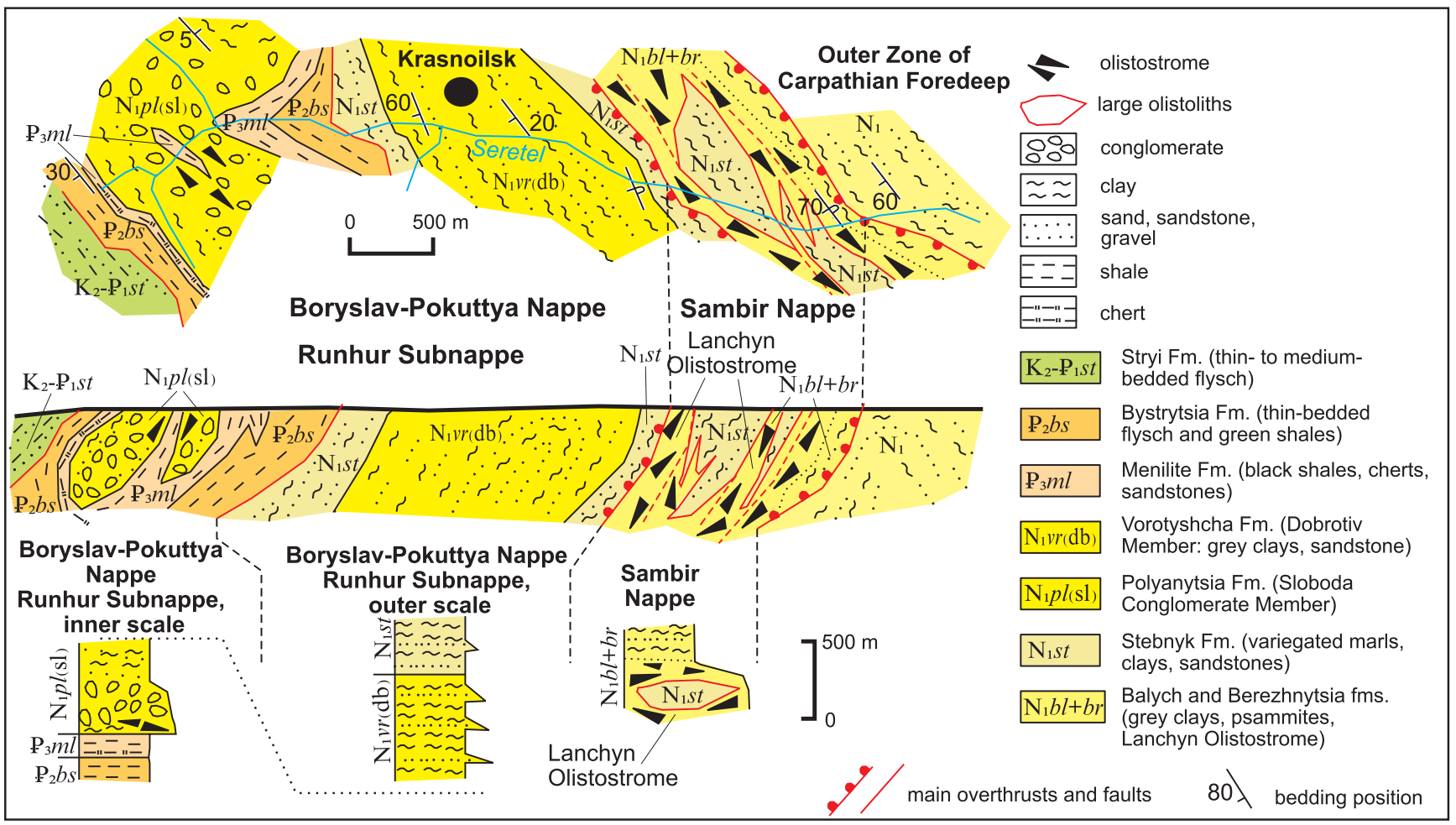

Fig. 5. Geologic map and cross-section of the Boryslav-Pokuttya and Sambir units along the Seretel River and position of the olistostromes

For location see Figure 1 
these grey chaotic clayey deposits with gypsum veins are more similar to the matrix olistostrome they are the typical debris-flow deposits with clasts of red shale and marl of the Stebnyk Formation and other fragments of redeposited molasse (Fig. 6A-D). The grey matrix is considered as an integral element of the Balych Formation that contains the olistoliths (Fig. 6E; sizes from a few up to hundreds of metre across) of the Stebnyk Formation and rarely of the Vorotyshcha Formation.

The well-exposed section of the Lanchyn Olistostrome is located along the Seretel River near the Ukrainian-Romanian border (Fig. 5).

In the Seretel Section, beneath the thrusts of the BoryslavPokuttya Nappe, the Lanchyn Olistostrome comes to the surface. The olistostrome can be traced over $800 \mathrm{~m}$ downstream along the Seretel River. Here the visible thickness of the olistostrome is $500-800 \mathrm{~m}$. However, the true thickness may be considerably lower because the olistostrome has undergone intense tectonic deformation and possibly is divided into several tectonic slabs. The matrix of the Lanchyn Olistostrome is semi- lithified, often intensely gypsiferous, grey-blue clay with chaotic, poorly layered sedimentary textures (Fig. 6A, D). Olistoliths are of more strongly lithified red-brown and grey shale, marl and sandstone of the Stebnyk Formation. Small clasts are composed also of sandstone, grey and red shale and marl of the Stebnyk Formation.

Rocks in the olistoliths are often strongly folded, sheared, in places transformed into tectonic breccia up to melange (Fig. $7 \mathrm{~A})$ and are very similar to the tectonically deformed deposits of the Stebnyk Formation developed in front of the BoryslavPokuttya Nappe (Fig. 7B). These internally deformed olistoliths were probably derived from the uplifted front of BoryslavPokuttya Nappe.

Nannoplankton of the NN5 zone and the lower Middle Miocene foraminifers: Globoquadrina altispira (Cushman et Jarvis), Globigerinoides trilobus (Reuss), Gl. aff. bisphaericus Todd, Globigerina bulloides (d'Orbigny), G. foliata Bolli, Turborotalita quinqueloba (Natland), Globigerinella obesa (Bolli), Bulimina elongata d'Orbigny, B. striata striata d'Orbigny, Praeglobo-
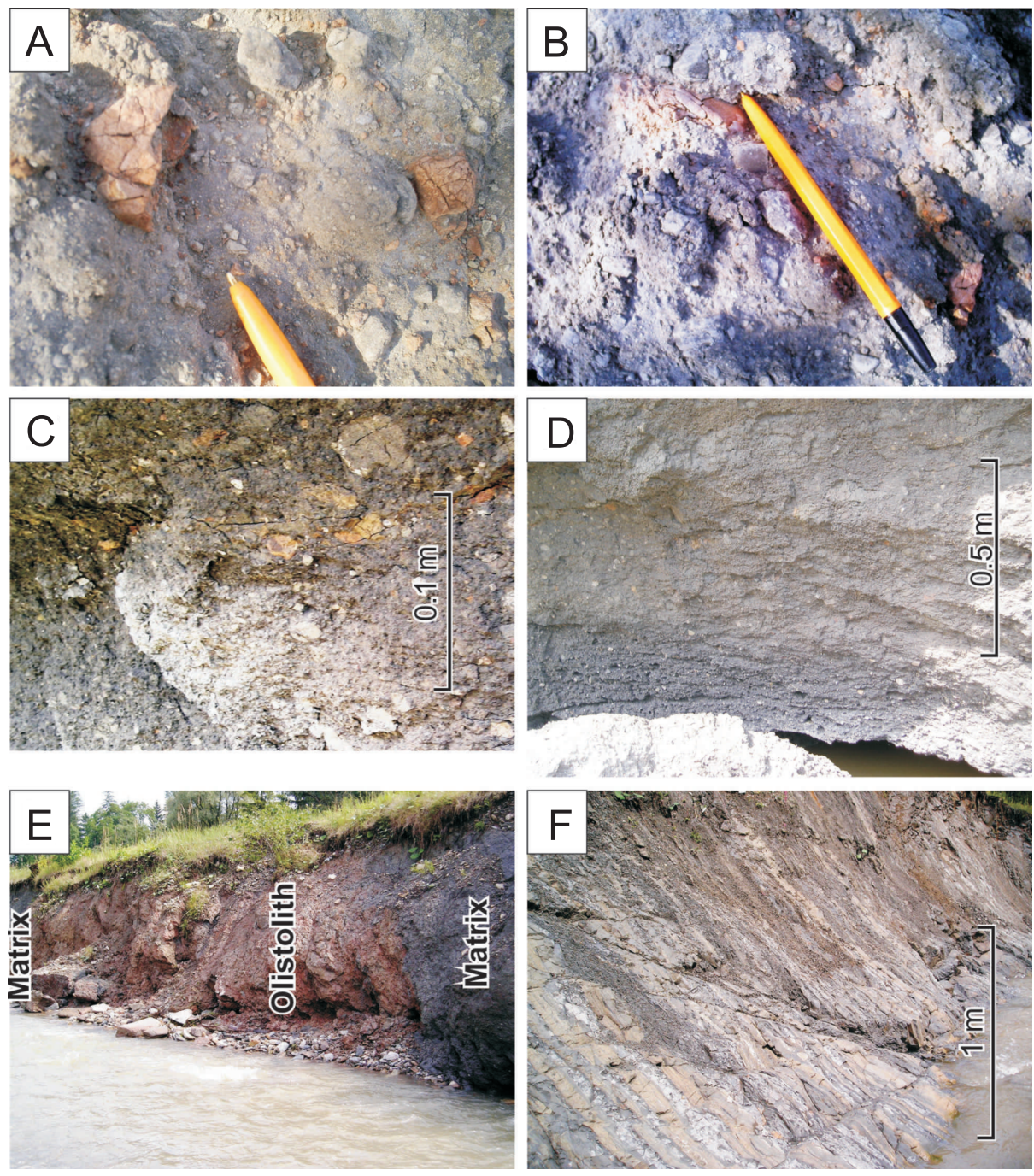

Fig. 6. Lanchyn Olistostrome of the Balych Formation ahead the front of Boryslav-Pokuttya Nappe

A, B - matrix of the olistostrome - debris-flow deposits with clasts of the Stebnyk Marls (Prut River near Lanchyn); C, D - matrix of the olistostrome (Seretel River near Krasnoilsk); E - olistolith of the Stebnyk Formation (Seretel River near Krasnoilsk); F - layered deposits of the Balych Formation that stratigraphically overlie the Lanchyn Olistostrome (Seretel River near Krasnoilsk) 

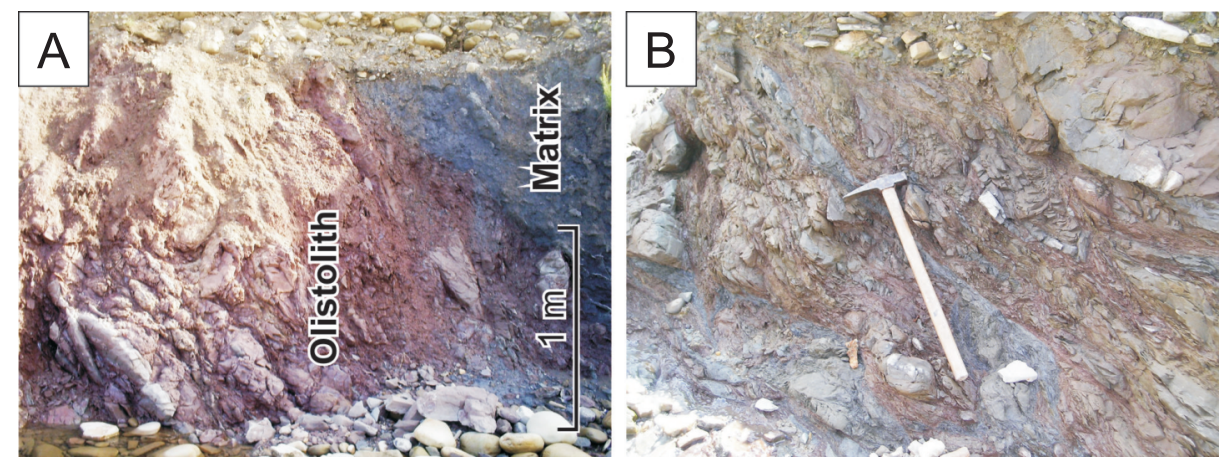

Fig. 7A - folded and sheared rocks (red marls, shales, sandstones of the Stebnyk Formation) within the olistolith of the Lanchyn Olistostrome (Seretel River near Krasnoilsk); B folded and sheared rocks of the Stebnyk Formation in the front of Boryslav-Pokuttya Nappe (Seretel River near Krasnoilsk)

The hammer length $0.8 \mathrm{~m}$

bulimina pupoides (d'Orbigny) and Ammonia beccarii (Linne), were found in the Lanchyn Olistostrome (Andreyeva-Grigorovich et al., 2008b; Vashchenko et al., 2009). These findings confirm the assumption that the Lanchyn Olistostrome is a component of the Balych Formation.

Downstream along the Seretel River the grey chaotic clayey matrix of the Lanchyn Olistostrome gradually built up the laminated clayey shales with sandstone intercalations (Fig. 6F) which belong to the Balych and Berezhnytsia formations containing nannoplankton of the NN5-NN8 zones (AndreyevaGrigorovich et al., 2008b; see Fig. 2).

Below, along the Seretel River, the autochthonous molasse - layered sandstones and clays of the Outer Zone of the Carpathian Foredeep, are exposed (see Fig. 5).

Thus, the structural position of the Lanchyn Olistostrome (ahead front of the Boryslav-Pokuttya Nappe) and its composition (the presence of olistoliths of strongly deformed rocks analogous to the rocks in the frontal part of the Boryslav-Pokuttya Nappe) suggest that the olistostrome was accumulated due to denudation of the uplifted front of the moving Boryslav-Pokuttya Nappe in its foreland.

\section{DISCUSSION}

Around of the Paleogene and Neogene boundary, the Boryslav-Pokyttya Unit together with the Skyba, Sub-Silesian and Silesian units formed the remnant Outer Carpathian flysch basin on the structures of the Eurasian passive margin. The residual Outer Carpathian flysch basin was limited along the south-west side by the accretionary prism composed of the Inner Flysch Nappes (Chornohora, Svydovets, Dukla and others, see Fig. 1). The growth of the prism took place in front of the moving ALCAPA and Tisza-Dacia terranes due to subduction of the substrate of the Outer Carpathian sedimentary basin beneath these terranes. Miocene molasse, including the olistostromes described, were formed due to fold-thrust movements of the accretionary prism during the transition from the remnant flysch to a peripheral foreland basin (Csontos and Vörös, 2004; Oszczypko, 2006; Hnylko, 2012).

In the Oligocene and Early Miocene, deep-water flysch sedimentation in the Boryslav-Pokuttya Basin gradually changed to shallow molasse (including evaporite) deposition, probably due to a general synsedimentary uplift of the basin. This uplift may have been an expression of the vertical component of thrusting of the Boryslav-Pokuttya Nappe on the edge of Eurasia (platform) (Fig. 8). Synsedimentary movements led to the growth of anticlinal and/or thrust-anticlinal walls from which olistoliths of the flysch and molasse rocks were slid to the adjacent synclinal depressions (for example, the Akreshory synclinal trough, see Fig. 4). This process led to the formation of the PolyanytsiaVorotyshcha olistostrome into the inner part (piggy-back basin) of the moving Boryslav-Pokuttya Nappe (Fig. 8).

In the Early Miocene the fore-bulge was formed at the foreland of the Boryslav-Pokuttya Nappe (which was transformed at this time into the forward moving nappe of the Carpathian accretionary prism). The forebulge supplied the exotic material for the Sloboda Conglomerate and its analogues. Most thick and proximal sequences of the Sloboda Conglomerate are located along the border between the Boryslav-Pokuttya Unit and the Sambir Unit, which can be observed in exposures along the southeastern part of the Ukrainian Carpathians between the Bystrytsia Nadvirnyanska and Seretel rivers. This position clearly indicates the now buried ancient source area, which supplied exotic clasts into the conglomerate. Obviously the source of supply of the exotic platform-derived debris (the flexural forebulge known us "Zuber Ridge", see Fig. 2) was placed (at least in the SE part of the region) between the BoryslavPokuttya and Sambir palaeobasins (Fig. 8). This situation suggests that the Sambir sedimentary basin was located north-east of the platform forebulge (the hypothetical source area) and thus was situated on the platform basement.

In the Middle Miocene the Boryslav-Pokuttya Nappe gradually tectonically covered the fore-bulge and began to cover the Sambir foredeep basin. Olistoliths from the uplifted front of the Boryslav-Pokuttya Nappe were transported into the foredeep basin, where the Lanchyn Olistostrome was formed (Fig. 8).

\section{CONCLUSIONS}

The origin of two olistostrome complexes at the front of the Ukrainian Carpathian orogen is related to synsedimentary Miocene thrust movements of the Carpathian accretionary wedge and to erosion of the uplifted areas of the Boryslav-Pokuttya Nappe (the forward nappe of the wedge).

The first complex is the Lower Miocene PolyanytsiaVorotyshcha Olistostrome with clasts of molasse and flysch de- 


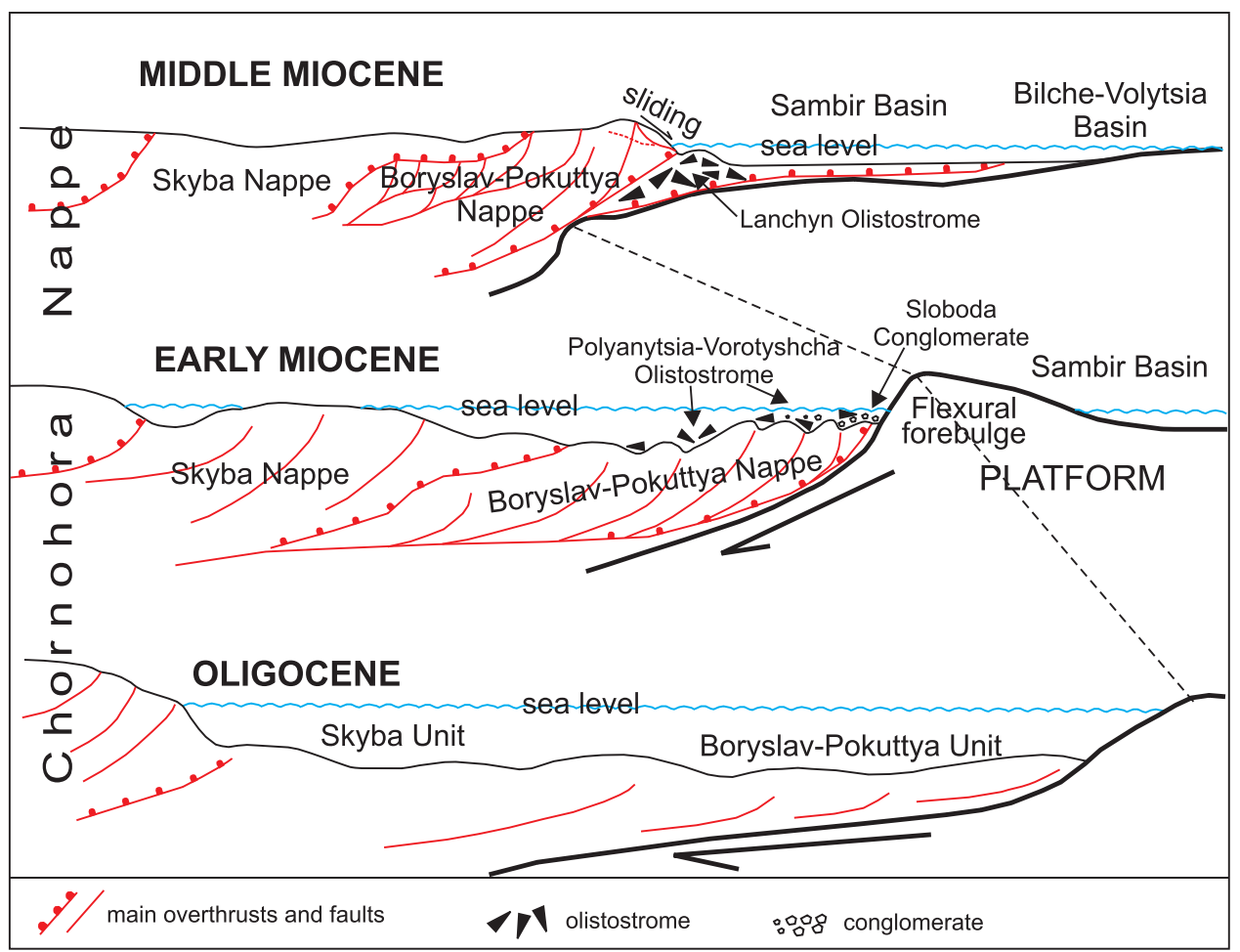

Fig. 8. Scheme of formation of the olistostromes of the Boryslav-Pokuttya and Sambir units of the southeastern part of the Ukrainian Carpathian orogen (after Hnylko and Vashchenko, 2004, modified)

posits. It was formed in the inner part of the Boryslav-Pokuttya Nappe on top of the accretionary wedge (in a piggy-back basin). This olistostrome is associated with the Sloboda Conglomerate derived from the platform fore-bulge located at the foreland of the Boryslav-Pokuttya Nappe.

The second is the Middle Miocene Lanchyn Olistostrome with olistoliths of strongly deformed molasse rocks, mainly of the Stebnyk Formation. These olistoliths were derived from the uplifted front of the Boryslav-Pokuttya Nappe. The Lan- chyn Olistostrome was deposited ahead of this front in the foredeep basin.

Acknowledments. I am very grateful to the Head of the Geological Mapping Department of the Lviv Geological Expedition, V.O. Vashchenko, for shared geological fieldwork and useful discussions. I thank Y. Koltun, M. Krobicki, T.M. Peryt and an anonymous reviewer for their constructive remarks.

\section{REFERENCES}

Andreyeva-Grigorovich, A.S., Kulchitsky, J.O., Lozynyak, P.J., Petrashkevich, M.I., Portnyagina, L.O., Ivanina, A.V., Smirnov, S.E., Trofimovich, N.A., Savitskaya, N.A., Shvareva, N.J., 1997. Regional stratigraphic scheme of Neogene formations on the Central Paratethys in the Ukraine. Geologica Carpathica, 48: 123-136

Andreyeva-Grigorovich, A.S. Oszczypko, N., Savitskaya, Ślączka, A., Trofimovich, N., 2003. Correlation of the Badenian salts of the Wieliczka, Bochnia and Kalush areas (Polish and Ukrainian Carpathian Foredeep). Annales Societatis Geologorum Poloniae, 73: 6-89.

Andreyeva-Grigorovich, A.S., Oszczypko, N., Ślączka, A., Oszczypko-Clowes, M., Savitskaya, N., Trofimovich, N., 2008a. New data on the of the folded Miocene Zone at the front of the Ukrainian Outer Carpathians. Acta Geologica Polonica, 58: 325-353.

Andreyeva-Grigorovich, A.S., Vashchenko, V.O., Hnylko, O.M., Kulyanda, M.J., Trofimovich, N.A., 2008b. About diachronous boundaries of the lithostratigraphic subdivisions of Neogene deposits of Boryslav-Pokuttya and Sambir nappes from the Ukrainian Pre-Carpathians (in Ukrainian with English summary). In:
Biostratyhrafichni osnovy pobudovy stratyhrafichnykh skhem fanerozoyu Ukrayiny. Zbirnyk Naukovykh Prats Instytutu Heolohichnykh Nauk NAN Ukrainy (ed. P.F. Hozhyk): 199-204. Noraprint, Kyiv.

Andreyeva-Grigorovich, A.S., Vashchenko, V.O., Hnylko, O.M., Trofimovich, N.A., 2011. Stratigraphy of Neogene deposits of the Ukrainian Carpathians and Carpathian Foreland (in Ukrainian with English summary). Tektonika i Stratyhrafiya, 28: 67-77.

Astakhov, K.P., 1989. Alpiyskaya geodinamika Ukrainskikh Karpat (in Russian). Avtoref. Disertatsii Kand. Geol.-Min. Nauk., MGU, Moskva.

Berggren, W.A., Kent, D.V., Swisher, C.C. III., Aubry, M.P., 1995. A revised Cenozoic geochronology and chronostratigraphy. SEPM Special Publication, 54: 129-212.

Burov, V.S., Vishnyakov, I.B., Mykyta, B.V., Khadykin, F.T., Shakin, V.A., 1976. Konglomeraty stebnitskoy svity Predkarpatya (in Russian). Geologiya i Geokhimiya Goryuchikh Iskopayemykh, 46: 34-40.

Byzova, S.L., 1965. Podvodno-opolznevyye obrazovaniya $v$ nizhnemelovykh otlozheniyakh Chyvchynskikh gor (Vostochnyye 
Karpaty) (in Russian). Biuletin Moskovskogo Obshchestva Ispytateley Prirody. Otdel Geologicheskiy, (1): 164-176.

Cieszkowski, M., Golonka, J., Krobicki, M., Ślączka, A., Oszczypko, N., Waśkowska, A., Wendorff, M., 2009. The Northern Carpathians plate tectonic evolutionary stages and origin of olistoliths and olistostromes. Geodinamica Acta, 22: 1-26.

Csontos, L., Vörös, A., 2004. Mesozoic plate tectonic reconstruction of the Carpathian region. Palaeogeography, Palaeoclimatology, Palaeoecology, 210: 1-56.

Fedushchak, M.Y., 1962. Umovy utvorennya ekzotychnykh konhlomerativ vorotyshchenskoyi seriyi Peredkarpattya (in Ukrainian). Vydavnytstvo AN URSR, Kyiv.

Flores, G., 1959. Evidence of slump phenomena (Olistostromes) in areas of hydrocarbon exploration in Sicily. Proceedings 5th World Petroleum Congress, Sect. 1, pap. 13, Roma: 259-275.

Glushchenko, L.A., 1972. Geologicheskoye stroyeniye i podvodno-opolznevyye obrazovaniya yuzhnogo sklona Ukrainskikh Karpat v verkhovyakh Latoritsy i Riki (in Russian). Avtoref. disertatsii Kand. Geol.-Min. Nauk. Lvov.

Glushchenko, L.A., Zhigunova, Z.F., Kuzovenko, V.V., Lozynyak, P.Y., Temnyuk, F.P., 1980. Olistostromy v oligotsenovykh otlozheniyakh Krosnenskoy (Silezskoy) zony Ukrainskikh Karpat (in Russian). Materialy XI Kongr. KBGA. Litologiya: 55-64. Naukova Dumka, Kiev.

Glushko, V.V., Lozynyak, P.Y., Petrashkevich, M.I., 1982. Novyye predstavleniya o stroyenii i rayonirovanii Predkarpatskogo progiba (in Russian). Geologiya i Geokhimiya Goryuchikh Iskopayemykh, 58: 19-31.

Gruzman, A.D., Smirnov, S.Y., 1985. Olistostromy krosnenskoy svity Ukrainskikh Karpat (in Russian). Doklady AN USSR. Seriya B., geologicheskiye, khimicheskyie i biologicheskiye nauki, 4: $18-21$.

Hnylko, O.M., 2000. Chaotic formation of south-western part of the Krosno Zone - the products of origin and development of Dukla Nappe (Ukrainian Carpathians) (in Ukrainian with English summary). Geodynamika, 3: 65-74.

Hnylko, O., 2011. Principles of distinguishing, features, classification and genesis of the olistostromes and melanges of the Ukrainian Carpathians (in Ukrainian with English summary). Visnyk Lvivskoho Derzhavnoho Universytetu. Seria "Heolhiya", 25: 20-35.

Hnylko, O.M., 2012. Tectonic zoning of the Carpathians in terms of the terrane tectonics Article 2. The Flysch Carpathian - ancient accretionary prism (in Ukrainian with English summary). Geodynamika, 12: 67-78.

Hnylko, O.M., Vashchenko, V.O., 2003. New point of view on the geologic structure of the Boryslav-Pokuttya and Sambir nappes of the Ukrainian Pre-Carpathians (in Ukrainian with English summary). Heolohiya i Heokhimiya Horyuchykh Kopalyn, (2): 63-75.

Hnylko, O.M., Vashchenko, V.O., 2004. Evolution of the BoryslavPokuttya and Sambir Nappes and tectonic setting Miocene molasse basins (Ukrainian Pre-Carpathians) (in Ukrainian with English summary). Geodynamika, 4: 24-39.

Jankowski, L., Kopciowski, R., Ryłko, W., eds., 2007. Geological map of the Outer Carpathians: borderland of Ukraina and Romania 1:200 000. Państwowy Instytut Geologiczny, Warszawa.

Jankowski, L., Kopciowski, R., Ryłko, W., Danysh, V., Tsarnenko, P., Hnylko, O., 2012. Lithostratigraphic correlation of the Outer Carpathian borderlands of Poland, Ukraine, Slovakia and Romania. Biuletyn Państwowego Instytutu Geologicznego, 449: 87-98.

Kosakowski, P., 2013. 1-D modelling of hydrocarbon generation and expulsion from Oligocene Menilite source rocks in the San and Stryi rivers region (Polish and Ukrainian Carpathians). Geological Quarterly, 57 (2): 30-324.

Kovač, M., Nagymarosy, A., Oszczypko, N., Ślączka, A., Csontos, L., Marunteanu, M., Matenco, L., Márton, M., 1998. Palinspastic reconstruction of the Carpathian-Pannonian region during the Miocene. In: Geodynamic development of the Western Carpathians (ed. M. Rakus): 189-217. Geological Survey of Slovak Republic, Bratislava.

Kruglov, S.S., 1965. O prirode Marmaroshskikh utesov Sovetskikh Karpat (in Russian). Geologicheskiy sbornik Lvovskogo geologicheskogo obshchestva, 9: 41-54.

Kruglov, S.S., ed., 1986. Tektonika Ukrainskikh Karpat (obyasnitelnaya zapiska k tektonicheskoy karte Ukrainskikh Karpat m-ba 1:200 000) (in Russian). Naukova Dumka, Kiyev.
Kulchitskiy, Y.O., 1977. Olistolity, olistostromy i drugiye podvodnoopolznevyye yavleniya vo flishe Vostochnykh Karpat (in Russian). In: Geologia i polyeznyye iskopayemyye Ukrainskikh Karpat, chast 2 (eds. Y. Kulchitskiy and O. Matkovskiy): 44-54. Vyshcha shkola, Lvov.

Kulyanda, M., Hnylko, O., 2012. Verification of the stratigraphy of Neogene molasses of the Boryslav-Pokuttya and Sambir Nappes in the north-western part of the Ukrainian Precarpathians (in Ukrainian with English summary). Heolohiya i Heokhimiya Horyuchykh Kopalyn, 158, 159 (1-2): 36-50.

Leonov, M.G., 1981. Olistostromy v strukture skladchatykh oblastyei (in Russian). Nauka, Moskva.

Martini, E., 1971. Standard Tertiary and Quaternary calcareous nannoplankton zonation. In: Proceedings of the Second Planktonic Conference Roma 1970 (ed. A. Farinacci): 739-785. Ed. Tecnoscienza, Roma.

Oszczypko, N., 2006. Late Jurassic-Miocene evolution of the Outer Carpathian fold-and-thrust belt and its foredeep basin (Western Carpathians, Poland). Geological Quarterly, 50 (1): 169-194.

Oszczypko, N., Krzywiec, P., Popadyuk, l., Peryt, T., 2006. Carpathian Foredeep Basin (Poland and Ukraine): its sedimentary, structural, and geodynamic evolution. AAPG Memoir, 84: 261-318

Oszczypko, N., Uchman, A., Bubniak, I., 2012. Foreland provenance of thick conglomerates in the early stages of Carpathian Foredeep development: the case of the Sloboda Conglomerate (Lower Miocene), western Ukraine. Geological Quarterly, 56 (4): 789-802.

Peryt, T.M., 2006. The beginning, development and termination of the Middle Miocene Badenian salinity crisis in Central Paratethys. Sedimentary Geology, 188-189: 379-396.

Tołwiński, K., 1950. The Pokutie Carpathian (in Polish with English summary). Acta Geologica Polonica, 1: 159-256.

Schmid, S., Bernoulli, D., Fugenschuh, B., Matenco, L. Schefer, S., Schuster, R., Tischler, M., Ustaszewski, K., 2008. The Alpine-Carpathian-Dinaric orogenic system: correlation and evolution of tectonic units. Swiss Journal of Geosciences, 101: 139-183.

Smirnov, S.E., 2003. Paradoxes and problems of Fore-Carpathian Neogene stratigraphy (in Ukrainian with English summary). Zbirnyk Naukovykh Prats, UkrDGRI 2: 63-70.

Ślączka, A., Kolasa, K., 1997. Resedimented salt in the Northern Carpathians Foredeep (Wieliczka, Poland). Slovak Geological Magazine, 3: 135-155.

Vashchenko, V., Hnylko, O., Maletych, Y., Chernukha, Z., Brytan, A., Savytska, N., Trofymovych, N., Boltruchuk, P., 2001. Heolohichna budova solenosnoyi molasy Ukrayinskoho Peredkarpattya. Unpublished report. Archives of PGO "Zapukrgeologiya". Lviv.

Vashchenko, V.O., Hnylko, O.M., 2003a. About stratigraphy and sedimentary features of the Neogene molasse of the Boryslay-Pokuttya and Sambir Nappes of the Ukrainian Fore-Carpathians (in Ukrainian with English summary). Heolohiya i Heokhimiya Horyuchykh Kopalyn, (1): 87-101.

Vashchenko, V.O., Hnylko, O.M., 2003b. About stratigraphy of the salt-bearing molasse of the Ukrainian Fore-Carpathians (in Ukrainian with English summary). Zbirnyk Naukovykh Prats, UkrDGRI, 2: 71-77.

Vashchenko, V.O., Andryeyeva-Gryhorovych, A.S., Hnylko, O.M., Potylytskyy, D.V., Trofymovych, N.A., 2009. Litolohofatsialnyy analiz rozriziv miotsenovykh molas BoryslavskoPokutskoyi ta Sambirskoyi strukturno-fatsialnykh zon Peredkarpatskoho prohynu z metoyu modernizatsiyi stratyhrafichnoyi skhemy (in Ukrainian). Unpublished report. Archives of PGO "Zapukrgeologiya". Lviv.

Vialov, O.S., 1965. Stratigrafiya neogenovykh molas Predkarpatskogo progiba (in Russian). Naukova Dumka, Kiev.

Wójtowicz, A., Hryniv, S.P., Peryt, T.M., Bubniak, A., Bubniak, I., Bilonizhka, P.M., 2003. K/Ar dating of the Miocene potash salts of the Carpathian Foredeep (West Ukraine): application to dating of tectonic events. Geologica Carpathica, 54: 243-249.

Young, J., 1998. Miocene. In: Calcareous Nannofossil Biostratigraphy (ed. P. Bown): 225-265. Kluwer Academic Publishers. 